\title{
Evaluation of Neuroprotective Potential of Some Newly Synthesized Benzopyran-2-One Derivatives in Swiss Albino Mice
}

\author{
Arif Hussain Tippu ${ }^{1, *}$, Imaduddin Mohammed², Koti Basavaraj Chanabasappa ${ }^{1}$, Ronad Pradeep \\ Mallikarjun ${ }^{1}$
}

1Department of Pharmacology, KLE University's College of Pharmacy, Hubli-580031, Karnataka, INDIA.

2Department of Pharmacology, Pulla Reddy Institute of Pharmacy, Gummadidala, Domadugu, Sangareddy, Telangana-502313, INDIA.

\begin{abstract}
Background: Present study was carried out to evaluate neuroprotective activity of newly synthesized Benzopyran-2-one derivatives. Methods: Three compounds namely 7-(2-(o-furan)-phenyl thiazolidinyl)-4-methyl benzopyran-2-one (FPTMB), 7-(2-(N,N dimethyl)-phenyl thiazolidinyl)-4-methyl-benzopyran-2-one (DPTMB) and 7-(2-(p-hydroxy)phenyl thiazolidinyl)-4-methyl-benzopyran-2-one (HPTMB) were assessed for their effects on Central Nervous System (CNS) using a series of established pharmacological tests including evasion test for anxiolytic activity, actophotometer test for spontaneous motor activity (SMA), rotarod test for skeletal muscle relaxation and pentylenetetrazole (PTZ) induced convulsant model for anti-convulsant activity followed by Eddy's hot plate and Haffner's tail clip method for analgesic activity. Results: These derivatives were found to produce symptoms of CNS depression in conscious mice, viz. significant reduction in SMA and exploratory behavior by evasion test and skeletal muscle relaxation and showed a significant prolongation of latency and reduced duration of convulsions induced by PTZ. Further, these test compounds failed to show a significant anti-nociceptive activity evaluated by centrally acting analgesic models i.e., Eddy's hot plate and Haffner's tail clip methods. Conclusion: It may be concluded that all three derivatives possess anxiolytic activity, SMA, skeletal muscle relaxation and anti-convulsant activity but do not possess analgesic activity.
\end{abstract}

Key words: Benzopyran-2-one derivatives, Actophotometer, Eddy's hot plate, Evasion test, Epilepsy.

\section{INTRODUCTION}

In neurodegenerative diseases death of neurons in the brain and spinal cord is the major reason for the loss of sensory and cognitive functions. ${ }^{1}$ Successful progress has been made by pharmaceutical industry in recent years on wide range of diseases but the treatment of CNS disorders is lagging behind. ${ }^{2}$ Treatment of these disorders mainly deals with the selective delivery of the therapeutic agent to the target cell. ${ }^{3}$ Combination drug therapy is mostly employed but their prolonged use may result in abnormal bodily movements, motor disturbances, confusion, behavioral changes ${ }^{4}$ etc., hence there is a need to develop a biologically active neuroprotectants with fewer or no side effects.

Coumarins are group of compounds reported to possess various effects on $\mathrm{CNS}$, is gaining tremendous interest in the field of neuropharmacological research. Different plants containing coumarin as an active ingredient reported for CNS activities Leucasinflate, ${ }^{5}$ Angelica gigas, ${ }^{6}$ Ficus platyphylla, Morus alba $L^{8}{ }^{8}$ Different chemically synthesized derivatives of coumarin known to possess various biological activities like
Submission Date: 06-10-2017; Revision Date: 17-05-2018; Accepted Date: 14-08-2018

DOI: 10.5530/ijper.52.4s.113 Correspondence: Mr. Arif Hussain $T$, Department of Pharmacology, KLE University's College of Pharmacy, Hubli-580031. Karnataka, INDIA Phone: +919247452028 E-mail: tarifpharma@gmail. com

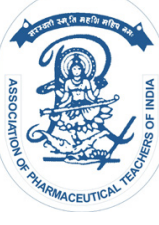

www.ijper.org 
anti-oxidant, ${ }^{9}$-lipoxygenase inhibitor, ${ }^{10}$ heat shock protein-90 inhibitor, ${ }^{11}$ multidrug transporter of $\mathrm{P}$-glycoprotein inhibitor. ${ }^{12}$ Therefore, present study deals with investigation of neuropharmacological effects of some newly synthesized benzopyran-2-one derivatives.

\section{MATERIALS AND METHODS}

\section{Chemicals}

All chemicals used in study are of analytical grade. Diazepam and GABA were procured as marketed formulation from Azardo Pharmaceuticals, Pentazocine from Ranbaxy Lab. Ltd and PTZ from sigma-Aldrich chemical company, USA. Normal saline (NS) (5 ml/kg, P.O) was used as control in all experiments.

\section{Animals}

Experimental protocol was carried out by using female Swiss albino mice weighing 20-25 g were procured from the animal house of K.L.E.S College of Pharmacy, Hubli, and Karnataka. Standard guidelines of CPCSEA are followed to carry out all experimental protocols. During the study all animals were kept in clean cages and provided with standard rodent feed and water ad-libtum. This experimental study was approved by Institutional Animal Ethical Committee of KLE College of Pharmacy, Hubli, Karnataka, India, with the approval number of KLESCOPH/IAEC. Clear/2011 -2012/05.

\section{Synthesis and characterization of benzopyron-2- one derivatives}

7-(2-substituted phenylthiazolidinyl) - benzopyron-2one derivatives were obtained by using starting material 7-amino- 4- methyl - benzopyron - 2- one and a suitable substituted aldehydes. Schiff bases obtained from reaction of starting material were treated with thioglycolic acid to produce a series of derivatives of 7-(2-substituted phenylthiazolidinyl) - benzopyron-2- one. Synthesis and characterization of these compounds were publicized by Ronad et al. in 2010. ${ }^{13}$ Among these derivatives following three compounds namely FPTMB, DPTMB and HPTMB were selected for the present study to evaluate their neuro protective potential.

\section{Acute oral toxicity}

Guideline no.425 given by Organization for Economic Cooperation and Development (OECD) was followed to conduct toxicity studies. Mice of (swiss albino) body weight ranging from $20-25 \mathrm{~g}$ are used. ${ }^{14}$ In each step 3 animals were used in each group. Animals were kept on fasting for 3-4 h prior to dosing. All the animals were evaluated for the signs of toxicity and mortality.

\section{Experimental Design}

In order to screen synthesized derivatives for neuroprotective potential, mice (20-25g) of swiss albino strain (either sex) are used. For each type of activity animals were divided into five groups, of six each as follows:

\section{Group-I: $\quad$ Control - NS ( $5 \mathrm{ml} / \mathrm{kg}$ P.O.)}

Group-II: $\quad$ Standard - Diazepam $(10 \mathrm{mg} / \mathrm{kg}$ body weight, P.O.)/ Pentazocine $(10 \mathrm{mg} / \mathrm{kg}$, B.W, P.O. for Eddy's Hotplate and tail flick method)

Group-III: $\quad$ FPTMB $(20 \mathrm{mg} / \mathrm{kg}$ body weight, P.O. $)$ Group-IV: $\quad$ DPTMB $(20 \mathrm{mg} / \mathrm{kg}$ body weight, P.O.) Group-V: $\quad$ HPTMB $(20 \mathrm{mg} / \mathrm{kg}$ body weight, P.O.)

\section{SMA by Actophotometer ${ }^{15}$}

Grouping of animals and treatment was done according to procedure described above. To see the locomotor activity, Actophotometer was turned $\mathrm{ON}$ and each mouse was placed individually in activity cage and observed for $10 \mathrm{~min}$. Basal activity score for all animals was noted ( 0 min reading). After administration of drug as described above, readings are noted at 30, 60, 90 and $120 \mathrm{~min}$. Difference in activity, before and after drug administration, was noted.

\section{Anxiolytic Effect by Evasion test}

In Evasion test animals are placed in rectangular box with an inclined plane $\left(45^{\circ}\right)$ by which it can escape from box. Animals which escaped with in $5 \mathrm{~min}$ are selected for test. After administration of drugs as described above, group wise animals were placed in box and number of mice remained in box after $5 \mathrm{~min}$ of test duration was noted. Readings are taken at 30, 60, 90 and 120 min after dose administration. ${ }^{16}$

\section{Skeletal Muscle Relaxant activity by Rotarod test}

Muscle relaxant activity was evaluated by testing potential of mice to remain on rotating rod. Animals were trained for using in test, mice which remained on rotating rod for $1 \mathrm{~min}$ into successive trials were selected for test. $30 \mathrm{~min}$ after administration of drugs as described above animals were placed on rod to note the time taken for mice to fall from rod. ${ }^{17}$

\section{Anti-Convulsant activity by PTZ induced seizures}

$1 \mathrm{hr}$ after administration of drugs as described above, PTZ $(80 \mathrm{mg} / \mathrm{kg}$ ) was given and time taken for onset, duration of seizures and mortality was noted. Percentage 
of animals protected with in $60 \mathrm{~min}$ after PTZ administration was also recorded. ${ }^{18}$

\section{Analgesic activity by Eddy's hotplate method ${ }^{19}$}

Mice showing cut off time below $15 \mathrm{sec}$ were selected for test and divided in to 5 groups as described above. Animals were placed on Hotplate where the temperature was set at $55 \pm 1^{\circ} \mathrm{C}$ and recorded the reaction time in seconds for licking of hind paw or jumping with cutoff time of 15 seconds to avoid injury. Reaction time was measured at 0, 30, 60, 90 and 120 min after administering with normal saline ( $5 \mathrm{ml} / \mathrm{kg}$ P.O.), standard Pentazocine (10 mg/ kg BW, P.O.), and FPTMB (20 mg/kg BW, P.O.), DPTMB (20 mg/kg BW, P.O.), HPTMB (20 mg/kg BW, P.O.) for their respective group animals.

\section{Analgesic activity by Tail clip method ${ }^{20}$}

Analgesic activity was also evaluated by applying a metal artery clip to the base of the tail with its jaws sheeted with rubber tubing. Pressure of the clip was so adjusted that it was just sufficient to make all control mice respond. Animals showing efforts to dislodge the clip within 15 seconds were only used and divided in to five groups(6 in each). Readings were taken at 0, 30, 60, 90 and $120 \mathrm{~min}$ after oral administration of drugs to their respective groups. It was considered a positive analgesic response if there was no attempt to dislodge the clip within $15 \mathrm{sec}$ in any of four consecutive trials.

\section{Statistical analysis}

Results are formulated as mean \pm SEM and subjected to statistical analysis by using one way ANOVA followed by a non-parametric, Dunnett's multiple comparison test in a Graph pad prism software of version 5.0.

\section{RESULTS}

\section{Acute oral toxicity study}

After dosing animals were observed individually at least once during first $30 \mathrm{~min}$, periodically during first $24 \mathrm{~h}$ and daily up to 14 days. It was observed that there were no signs of toxicity and mortality at a dose of $200 \mathrm{mg} / \mathrm{kg}$. LD50 was calculated by using AOT425statpgm. $200 \mathrm{mg} / \mathrm{kg}$ body weight was found to be maximum non-lethal dose, therefore $20 \mathrm{mg} / \mathrm{kg}$ (i.e. $1 / 10^{\text {th }}$ ) was selected as test dose for all three derivatives.

\section{SMA by Actophotometer}

Diazepam (10mg/kg), FPTMB, DPTMB and HPTMB at a dose of $20 \mathrm{mg} / \mathrm{kg}$ caused highly significant $(p<0.001)$ reduction in SMA in mice as compare to control group at 30, 60, 90 and $120 \mathrm{~min}$ as compared to control group. (Table 1)

\section{Anxiolytic Effect by Evasion test}

In evasion test, after treatment with diazepam, FPTMB, DPTMB and HPTMB, there was a significant $(p<0.001)$ decrease in residual curiosity behavior of mice. In all treatment groups number of animals remained in the box increased significantly from $30 \mathrm{~min}$ to $120 \mathrm{~min}$ as compared to control group. (Table 2)

\section{Skeletal Muscle Relaxant activity by Rotarod test}

In rotarod test, animals treated with Diazepam $(10 \mathrm{mg} / \mathrm{kg})$ showed highly significant $(p<0.001)$ decrease in time to fall from rotating rod as compare to control group indicating its effectiveness producing muscle relaxation. DPTMB showed significant $(p<0.05)$ decrease and FPTMB, HPTMB treated animals showed highly significant $(p<0.001)$ decrease in time to fall from rotating rod as compared to control group. (Table 3)

\section{Anti-Convulsant activity by PTZ induced seizures}

In control group vehicle treated rats showed convulsion at $12.0 \pm 0.58 \mathrm{sec}$ for duration of $14.0 \pm 0.58 \mathrm{sec}$ after treatment with PTZ. Animals treated with Diazepam, FPTMB, DPTMB and HPTMB showed significant

\begin{tabular}{|c|c|c|c|c|c|}
\hline Treatment & $0 \mathrm{~min}$ & $30 \mathrm{~min}$ & $60 \mathrm{~min}$ & $90 \mathrm{~min}$ & $120 \mathrm{~min}$ \\
\hline $\begin{array}{c}\text { Control } \\
\text { (NS } 5 \mathrm{ml} / \mathrm{kg} \mathrm{B.W} \mathrm{P.O.)}\end{array}$ & $310.0 \pm 7.57$ & $303.0 \pm 8.185$ & $293.7 \pm 5.696$ & $298.3 \pm 7.796$ & $297.0 \pm 5.859$ \\
\hline $\begin{array}{c}\text { FPTMB } \\
(20 \mathrm{mg} / \mathrm{kg} \mathrm{B.W} \mathrm{P.O)}\end{array}$ & $316.0 \pm 10.3$ & $126.0 \pm 3.60^{6 * \star *}$ & $114.0 \pm 3.2^{15^{\star \star *}}$ & $65.33 \pm 6.3^{33^{* \star *}}$ & $44.33 \pm 4 .{ }^{66^{* * *}}$ \\
\hline $\begin{array}{c}\text { DPTMB } \\
\text { (20mg/kg B.W P.O) }\end{array}$ & $310.7 \pm 6.3$ & $182.0 \pm 8 .^{33^{* * *}}$ & $169.0 \pm 10 . .^{41^{* \star *}}$ & $139.7 \pm 9.0^{25^{* \star *}}$ & $123.7 \pm 4 . .^{63^{*} \star *}$ \\
\hline $\begin{array}{c}\text { HPTMB } \\
\text { (20mg/kg B.W P.O) }\end{array}$ & $302.7 \pm 5.70$ & $161.3 \pm 7 . .^{75^{* \star *}}$ & $151.7 \pm 8.8^{40^{* \star \star *}}$ & $127.3 \pm 2.0^{28^{* \star *}}$ & $142.0 \pm 15 .^{37^{* \star *}}$ \\
\hline $\begin{array}{c}\text { Diazepam } \\
\text { (10mg/kg B.W P.O) }\end{array}$ & $309.0 \pm 7.23$ & $26.67 \pm 3 .{ }^{180 * * *}$ & $9.333 \pm 0.8^{82^{* * *}}$ & $11.67 \pm 0.8^{81^{* * *}}$ & $10.00 \pm 1 . .^{15^{* * *}}$ \\
\hline
\end{tabular}




\begin{tabular}{|c|c|c|c|c|}
\hline \multirow[t]{2}{*}{ Treatment } & \multicolumn{4}{|c|}{$\begin{array}{l}\text { Number of animals }(n=6) \text { remaining in } \\
\text { the box after } 5 \text { min ( Mean of } 2 \text { values) }\end{array}$} \\
\hline & $30 \mathrm{~min}$ & $60 \mathrm{~min}$ & $90 \mathrm{~min}$ & $120 \mathrm{~min}$ \\
\hline $\begin{array}{c}\text { Control } \\
\text { (NS } 5 \mathrm{ml} / \mathrm{kg} \text { B.W P.O.) }\end{array}$ & 0 & 0 & 0 & 0 \\
\hline $\begin{array}{c}\text { FPTMB } \\
(20 \mathrm{mg} / \mathrm{kg} \mathrm{B} . W \text { P.O) }\end{array}$ & $4.0 \pm 0.0^{* * * *}$ & $5.0 \pm 0.0^{* * * *}$ & $4.5 \pm 0.5^{n+* *}$ & $5.0 \pm 0.0^{* * *}$ \\
\hline $\begin{array}{c}\text { DPTMB } \\
(20 \mathrm{mg} / \mathrm{kg} \mathrm{B.W} \mathrm{P.O)}\end{array}$ & $3.0 \pm 0.0^{* *}$ & $4.0 \pm 0.0^{* * * *}$ & $4.5 \pm 0.0^{* * * *}$ & $4.0 \pm 0.0^{* * *}$ \\
\hline $\begin{array}{c}\text { HPTMB } \\
(20 \mathrm{mg} / \mathrm{kg} \mathrm{B} . W \text { P.O) }\end{array}$ & $2.5 \pm 0.0^{* *}$ & $4.0 \pm 0.0^{* * *}$ & $3.5 \pm 0.5^{* *}$ & $3.5 \pm 0.5^{* *}$ \\
\hline $\begin{array}{c}\text { Diazepam } \\
(10 \mathrm{mg} / \mathrm{kg} \mathrm{B.W} \mathrm{P.O)}\end{array}$ & $5.5 \pm 0.5^{* * *}$ & $5.5 \pm 0.5^{* * *}$ & $6.0 \pm 0.0^{* * *}$ & $6.0 \pm 0.0^{* * *}$ \\
\hline
\end{tabular}

\begin{tabular}{|c|c|c|c|c|}
\hline \multicolumn{1}{|c|}{ Table 3: Effect of Benzopyran-2-one derivatives on (i) skeletal muscle relaxation in mice by Rotarod test and on } \\
(ii) PTZ induced seizures in mice.
\end{tabular}

$(p<0.001)$ delay in onset of convulsion and also duration of convulsions was decreased as compare to control group. (Table 3)

\section{Analgesic activity by Eddy's hotplate method}

Control animals showed latency time of $1.3 \mathrm{sec}(0 \mathrm{~min})$ to $1.54 \mathrm{sec}(120 \mathrm{~min})$, administration of Pentazocine $(10 \mathrm{mg} / \mathrm{kg})$ resulted in significant increase in latency time from $1.48 \mathrm{sec}$ at $0 \mathrm{~min}$ to $5.00 \mathrm{sec}$ at $120 \mathrm{~min}(\mathrm{p}<0.001)$. All three benzopyran-2-one derivatives treated animals not showed significant change in latency time as compared to control group (data not shown).

\section{Analgesic activity by Tail clip method}

In tail clip method, control group animals showed reaction time of $2.02 \mathrm{sec}$ at $0 \mathrm{~min}$ to $2.3 \mathrm{sec}$ at $120 \mathrm{~min}$, pentazocine treated animals showed significant increase in reaction time to pain stimulus from $1.9 \mathrm{sec}$ at $0 \mathrm{~min}$ to $7.7 \mathrm{sec}$ at $120 \mathrm{~min}(p<0.001)$ as compared to control group. Moreover, reaction time in all three benzopyran-2-one treated groups, not increased significantly as compared to control animals (data not shown).

\section{DISCUSSION}

Results obtained in SMA showed that Benzopyran2-one derivatives decreases alertness and restlessness which were in agreement with previous reports where coumarins have been reported to possess sedative properties. ${ }^{21}$ Also there were neither tremors, twitches, convulsions nor straubs tail response. No effects were noticed on alarm reaction, body posture, limb position, gait, righting reflex, muscle tone and pinna and corneal reflexes. From such observations, it is possible to 
conclude that depressant effect of test compounds on locomotor activity was probably not due to a peripheral neuromuscular blockage. ${ }^{22}$ Diazepam, used as positive control in this test, belongs to the BZD group reduces SMA. Hence, we can say that all three Benzopyran2-one derivatives act like that of diazepam, by increasing the influx of $\mathrm{Cl}^{-}$ions through GABA channels. Spontaneous motor activity of benzopyran ring was also reported in a study done by Jadagoudar YP. ${ }^{23}$ By using same diazepam as a standard drug exploratory behavior was tested by using evasion test. There was significant increase in number of animals remaining in box after treatment with Benzopyran-2-one derivatives reporting their depressant action on CNS and also a strong indication of anxiolytic action as produced by diazepam. Anxiolytics are known to exert pharmacological action by causing an increase in the GABA content in the cerebral hemisphere in mice. ${ }^{16}$ Hence, we can conclude that all three Benzopyran-2-one derivatives used in present study act through BZD-GABA receptors, i.e., test derivatives might involve an action on GABAergic transmission as like that of diazepam. Our results are in accordance with the study of C Comoy et al. where they reported the efficacy of benzopyran ring as Anxiolytic agent against light-dark box test and the elevated plus maze test in mice. ${ }^{24}$

From results of rotarod test it was clear that all test compounds showed a significant relaxation of skeletal muscles as like that of diazepam. PTZ induced convulsions was used for screening anti-convulsant activity. Induction of seizures by PTZ is a very sensitive animal model of myoclonic seizures and allows detection of modulatory effects on convulsive tendency ${ }^{25}$ PTZ increases activity in major epileptogenic centers of forebrain like the amygdale and piriform cortex. ${ }^{26}$ Neurochemical evidence suggests that PTZ binds to picrotoxin and BZD sites of $\mathrm{GABA}_{\mathrm{A}}$ receptor complex. Suppression of inhibition mediated by GABA and/ or activation of NMDA receptors appears to be critical factors involved in the initiation and generalization of the PTZ-induced seizures. ${ }^{27}$ Enhancement and inhibition of neurotransmission of GABA will attenuate and enhance convulsion respectively. Thus, it may be possible that test compounds may have exerted anti-convulsant effects by enhancing GABAergic inhibitory neurotransmission similar to that of diazepam, which leads to opening of $\mathrm{Cl}^{-}$ion channel and influx of $\mathrm{Cl}^{-}$ions causing membrane hyperpolarization or by decreasing the degradation of GABA. Our findings of benzopyran ring showing anti-convulsant activity are similar to the results obtained by Ronad PM et al. where they proved the anti-convulsant efficacy of the same benzopyran ring against PTZ induced seizure model in mice. ${ }^{28}$ But the exact mechanism for increase in GABA content could not be reported in this study and remains to be explored.

Experimental evidence obtained in present laboratory animal study shows that all test compounds significantly delayed the onset of seizures and reduced duration of seizures induced by PTZ, FPTMB showed a significant reduction in the mortality rate of mice, whereas, DPTMB and HPTMB did not showed any protection of mortality in mice. According to previous studies synthetic compounds containing thiazolidine moiety in their structure demonstrate anticonvulsant activity. ${ }^{29-30}$ Thus, anticonvulsant activity of test compounds may be attributed to the thiazolidine moiety present in their structure. Hot plate method was selected to investigate central analgesic activity because it had several advantages; particularly sensitivity to strong anti-nociceptives and limited tissue damage. ${ }^{31}$ Pentazocine was used as a standard reference drug in hot plate method which acts through opioid receptors. Results of hot plate method showed that all test compounds did increased reaction time to heat stimulus but it was not statistically significant as compared to control group. Haffner's tail clip method is simple and has advantage that reflex mechanism on which it is based involves higher centers. Animal have to identify exactly place where noxious stimulus is applied and it carries out coordinated movements to remove it. ${ }^{32}$ In Haffner's tail clip method, animals significantly prolonged the latency to dislodge the clip from their tail in pentazocine group when compared with control group but the increase in latency to dislodge the clip by test compounds was not statistically significant compared to control. Results obtained from both analgesic tests for all three Benzopyran2-one derivatives showed that they had no analgesic effect. Based on our findings it is clear that these novel benzopyran ring derivatives can be explored at molecular level to find their neuroprotective activities and they should also be tested with other screening procedures to prove their non-analgesic activity.

\section{CONCLUSION}

Hence from results obtained of all neuropharmacological profiles in present study, it can be concluded that all three Benzopyran-2-one derivatives i.e. FPTMB, DPTMB and HPTMB possess neuropharmacological properties like anxiolytic activity, SMA, skeletal muscle relaxation and anti-convulsant activity, i.e., all the Benzopyran-2-one derivatives possess the depressant effects on CNS but do not possess analgesic activity. 
Further FPTMB was found to be more potent than DPTMB and HPTMB. Further evaluation of detail mechanism pathway involved in all the neuropharmacological profiles needs to be investigated.

\section{ACKNOWLEDGEMENT}

Authors are thankful to Mr. Patil BM, Principal KLE University's College of Pharmacy, Hubli, and Karnataka, India for their support and guidance during the work.

\section{CONFLICT OF INTEREST}

Nil.

\section{ABBREVIATIONS}

FPTMB: 7-(2-(o-furan)-phenyl thiazolidinyl)-4-methyl benzopyran-2-one; DPTMB: 7-(2-(N,N; dimethyl)phenyl thiazolidinyl)-4-methyl-benzopyran-2-one; HPTMB: 7-(2-(p-hydroxy)phenyl; thiazolidinyl)4-methyl-benzopyran-2-one; CNS: Central Nervous System; SMA: spontaneous motor Activity; PTZ: pentylenetetrazole; NS: Normal saline; OECD: Organization for Economic Cooperation and Development.

\section{REFERENCES}

1. Mattson MP. Metal-catalyzed disruption of membrane protein and lipid signaling in the pathogenesis of neurodegenerative disorders. Ann N Y Acad Sci. 2004;1012(1):37-50.

2. Dinunzio JC, Williams RO. CNS disorders- current treatment options and the prospects for advanced therapies. Drug Dev Ind Pharm. 2008;34(11):1141-67.

3. Miyashiro KY, Bell TJ, Sul JY, Eberwine J. Subcellular neuropharmacology: the importance of intracellular targeting. Trends Pharmacol Sci. 2009;30(4):203-11.

4. Foley P, Riederer P. Influence of neurotoxins and oxidative stress on the onset and progression of Parkinson's disease. J Neurol. 2000;247(2):82-94.

5. Al-Yousuf MH, Ali BH, Bashir AK, Tanira MO, Blunden G. CNS activity of Leucas inflata Benth in mice. Phytomedicine. 2002;9(6):501-7.

6. Kang SY, Kim YC. Neuroprotective Coumarins from the root of Angelica gigas: Structure- activity relationships. Arch Pharm Res. 2007;30(11):1368-73.

7. Wakeel OK, Aziba PI, Ashorobi RB, Umukoro S, Aderibigbe AO, Awe EO. Neuropharmacological activities of Ficus platyphylla stem bark in mice. Afr J Biomed Res. 2004;7(2):75-8.

8. Yadav AV, Kawale LA, Nade VS. Effect of Morus alba L leaves on anxiety in mice. Indian J Pharmacol. 2008;40(1):32-6.

9. Tyagi YK, Kumar A, Raj HG, Vohra P, Gupta G, Kumari R, et al. Synthesis of novel amino and acetyl amino-4-methylcoumarins and evaluation of their antioxidant activity. Eur J Med Chem. 2005;40(4):413-20.

10. Grimm EL, Brideau C, Chauret N, Chan CC, Delorme D, Ducharme Y, et al. Substituted coumarins as potent 5-lipoxygenase inhibitors. Bioorg Med Chem Lett. 2006;16(9):2528-31.

11. Radanyi C, Bras GL, Messaoudi S, Bouclier C, Peyrat JF, Brion JD, et al. Synthesis and biological activity of simplified denoviose-coumarins related to novobiocin as potent inhibitors of heat-shock protein 90 (hsp90). Bioorg Med Chem Lett. 2008;18(7):2495-8.

12. Raad I, Terreux R, Richomme P, Matera EL, Dumontet C, Raynaud J, et al. Structure-activity relationship of natural and synthetic coumarins inhibiting the multidrug transporter P-glycoprotein. Bioorg Med Chem. 2006;14(20):6979-87.

13. Ronad PM, Noolvi MN, Sapkal S, Dharbhamulla S, Maddi VS. Synthesis and antimicrobial activity of 7-(2-substituted phenylthiazolidinyl)-benzopyran-2onederivatives. Eur J Med Chem. 2010;45(1):85-9.

14. OECD (2008), Test No. 425: Acute Oral Toxicity: Up-and-Down Procedure, OECD Publishing, Paris. http://dx.doi.org/10.1787/9789264071049-en.

15. Shalam MD, Shantakumar SM, Narasu ML. Neuropharmacological Profile of Trans-01 a Polyherbal Formulation in Mice. Pharmacol online. 2007;1:146-51.

16. Yemitan OK, Salahdeen HM. Neurosedative and muscle relaxant activities of aqueous extract of Bryophyllum pinnatum. Fitoterapia. 2005;76(2):187-93.

17. Kuribara $\mathrm{H}$, Higuchi $\mathrm{Y}$, Tadokoro $\mathrm{S}$. Effects of central depressants on rotarodand traction performances in mice. Japan J Pharmacol. 1977;27(1):117-26.

18. Olayiwola G, Obafemi CA, Taiwo FO. Synthesis and neuropharmacological activity of some quinoxalinone derivatives. Afr J Biotech. 2007;6(6):777-86.

19. Eddy NB, Leimbach DJ. Synthetic analgesics. II Dithienylbutenyl and dithienyl butylamines. J Pharmacol Exp Ther. 1953;107(3):385-93.

20. Palanichamy S, Nagarajan S. Analgesic activity of Cassia alata leaf extract and kaempferol 3-o-sophoroside. J Ethnopharmacol. 1990;29(1):73-8.

21. Perez RMG, Perez JAL, Garcia LMD, Sossa HM. Neuropharmacological activity of Solanum nigrum fruit. J Ethnopharmacol. 1998;62(1):43-8.

22. Sarker SD, Uddin SJ, Shilpi JA, Rouf R, Ferdous ME, Nahar L. Neuropharmacological properties of Xylocarpus moluccensis. Fitoterapia. 2007;78(2):107-11.

23. Jadagoudar YP, Upase DS, Patil AP, Koti BC, Ronad PM. Neuropharmacological Profile Of Some Novel Coumarin Derivatives In Mice. Int J Pharm Biol Sci. 2014;3(4):216-42.

24. Comoy C, Marot C, Podona T, Baudin ML, Morin-Allory L, Guillaumet G, et al. 3-Amino-3,4-dihydro-2H-1-benzopyran Derivatives as 5-HT1A Receptor Ligands and Potential Anxiolytic Agents. 2 Synthesis and Quantitative Structure-Activity Relationship Studies of Spiro [pyrrolidine- and piperidine2,3'(2'H)-benzopyrans]. J Med Chem. 1996;39(21):4285-98.

25. Mandhane SN, Aavula K, Rajamannar T. Timed pentylenetetrazol infusion test: a comparative analysis with S.C. PTZ and MES models of anticonvulsant screening in mice. Seizure. 2007;16(7):636-44.

26. Gale K. Subcortical structures and pathways involved in convulsive seizure generation. J Clin Neurophysiol. 1992;9(2):264-77.

27. Loscher W, Honack D, Fassbender CP, Nolting B. The role of technical, biological and pharmacological factors in the laboratory evaluation of anticonvulsant drugs III Pentylenetetrazole seizure models. Epilepsy Res. 1991;8(3):171-89.

28. Ronad PM, Maddi VS, Koti BC, Kurhe YV, Swamy AHMV, Swamy AHMT, et al. Evaluation of Anti-Convulsant Activity of Novel Series of Benzopyran-2One Derivatives by PTZ Induced Seizure Model in Mice. Indian Journal of Novel Drug delivery. 2010;2(4):158-61.

29. Bhat MA, Siddiqui N, Khan SA. Synthesis of novel thioureido derivatives of sulfonamides and Thiosemicarbazido derivatives of coumarin as potential anticonvulsant and analgesic agents. Indian J Pharm Sci. 2006;68(1):120-4.

30. Amin KM, Rahman DEA, Al-Eryani YA. Synthesis and preliminary evaluation of some substituted coumarins as anti-convulsant agents. Bioorg Med Chem. 2008;16(10):5377-88.

31. Jaishree V, Badami S, Kumar MR, Tamizhani T. Antinociceptive activity of swertiamarin isolated from Enicostemmaaxillare. Phytomedicine. 2008;16(23):227-32.

32. Bianchi C, Franceschini J. Experimental observations on Haffner's method for testing analgesic drugs. Br J Pharmacol Chemother. 1954;9(3):280-4. 
PICTORIAL ABSTRACT

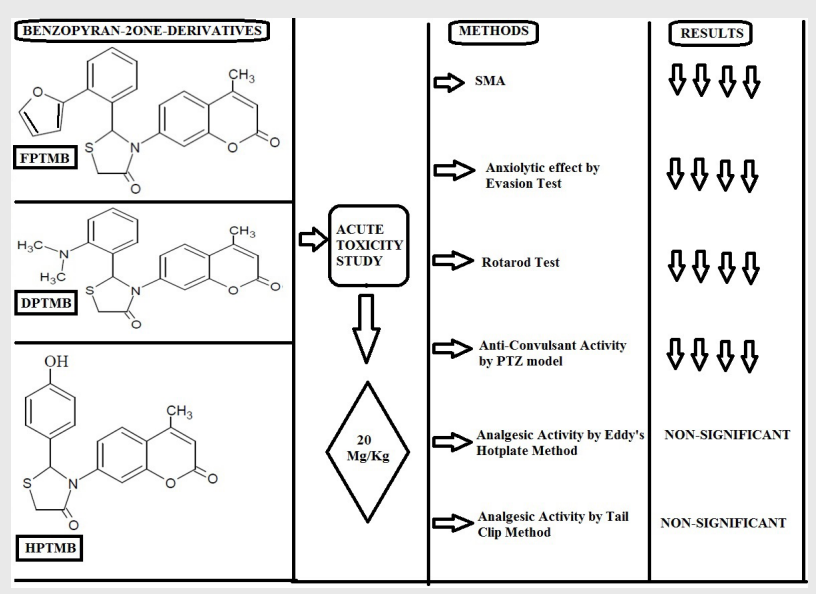

About Authors

\section{SUMMARY}

- Three Benzopyran-2-one derivatives FPTMB, DPTMB and HPTMB were screened for neuroprotective potential on CNS using various screening techniques like evasion test for anxiolytic activity, Actophotometer for SMA, rotarod test for skeletal muscle relaxation and PTZ Induced convulsant model for anti-convulsant activity followed by Eddy's hot plate and Haffner's Tail clip method for analgesic activity. All three derivatives produced CNS depression in mice, evidenced by significant reduction in SMA and also reduced exploratory behavior by evasion test and skeletal muscle relaxation and showed a significant prolongation of latency and reduced duration of convulsions induced by PTZ. Moreover, these three derivatives failed to show a significant anti-nociceptive activity. Based on results it can be concluded that all three derivatives possess anxiolytic activity, SMA, skeletal muscle relaxation and anti-convulsant activity but do not possess analgesic activity.

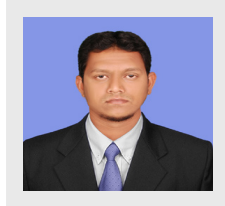

Tippu Arif Hussain working as a Assistant Professor since 4 years in MAK college of pharmacy, Moinabad in pharmacology department.

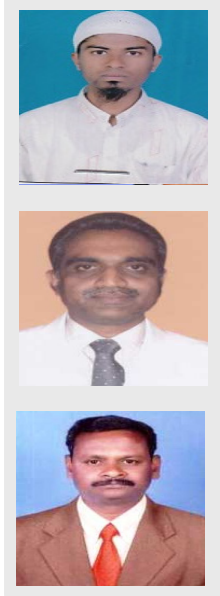

Mr. MD Imad Uddin, Assistant Professor at Pulla Reddy Institute of Pharmacy, Hyderabad. He had total of 6 years of experience.

BC Koti, professor and Head, Pharmacology Department, woking since 32 years in KLE college of Pharmacy, Hubli, Karnataka, area of interest in Neuro Protective Activity.

PM Ronad, professor and Head, Dept of Chemistry, working since 20 years in KLE College of Pharmacy Hubli, Karnataka, area of interest in Benzopyron derivatives.

Cite this article: Hussain AT, Imaduddin MD, Koti BC, Ronad PM. Evaluation of Neuroprotective Potential of Some Newly Synthesized Benzopyran-2-One Derivatives in Swiss Albino Mice. Indian J of Pharmaceutical Education and Research. 2018;52(4 Suppl 2):s326-s332. 